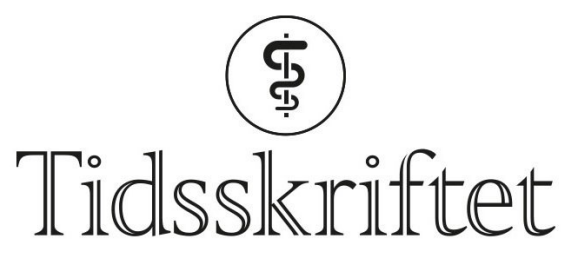

DEN NORSKE LEGEFORENING

\title{
Forside nr. 9/2019
}

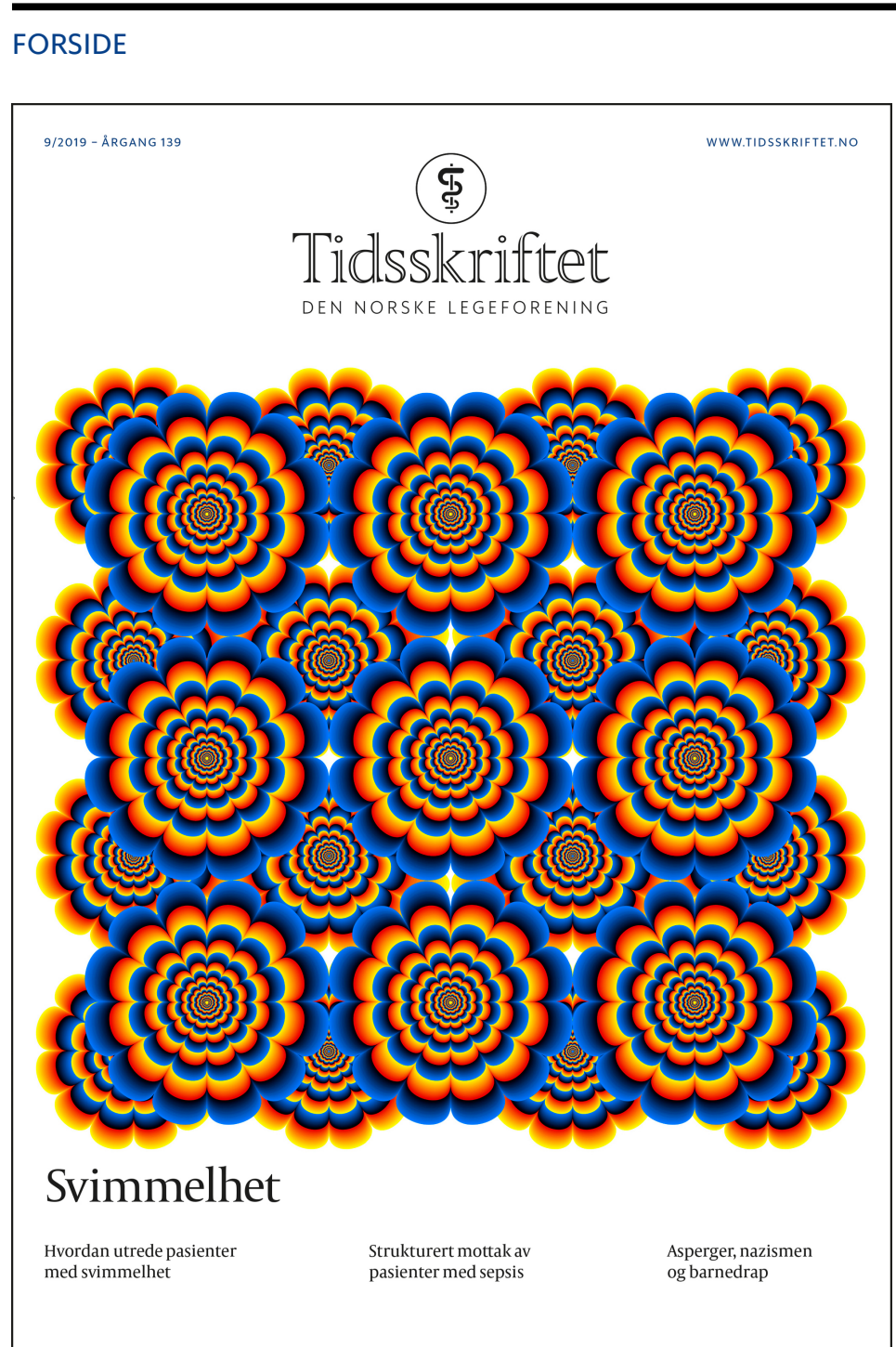

Illustrasjon (C Akiyoshi Kitaoka 2014/ Kanzen

Advarsel: Blue expansies er en optisk illusjon som kan gjøre tilskueren svimmel og uvel. Den er laget av Akiyoshi Kitaoka, professor i psykologi ved Ritsumeikan University i Kyoto.

Gjennom forskning på optiske illusjoner forsøker han å gi svar på hvordan hjernens system for visuell persepsjon fungerer. Flere av hans verker kan du se på tinyurl.com/akitaoka 